\title{
STATISTICAL VIEW OF EVALUATING \\ CONCRETE-SURFACE-LAYER PERMEABILITY TESTS IN CONNECTION WITH CHANGES IN CONCRETE FORMULA
}

\author{
STATISTIČNI POGLED NA OCENO PREIZKUSA PREPUSTNOSTI \\ POVRŠINSKE PLASTI BETONA V POVEZAVI S SPREMEMBAMI \\ FORMULE BETONA
}

\author{
Petr Misák, Tomáš Stavař, Iva Rozsypalová, Dalibor Kocáb, Petr Pőssl \\ Brno University of Technology, Faculty of Civil Engineering, Institute of Building Testing, Veveři 95, 60200 Brno, Czech Republic \\ possl.p@fce.vutbr.cz \\ Prejem rokopisa - received: 2015-07-14; sprejem za objavo - accepted for publication: 2016-06-06
}

doi:10.17222/mit.2015.223

Concrete is one of the most common building materials and its durability has been observed with increased attention. It can be said that concrete durability is closely connected with permeability and, generally speaking, the quality of its surface layer. Evaluating the quality of the surface layer of concrete is a rather difficult issue that can be addressed in different ways. The authors of this paper focus on three internationally used methods - TPT, GWT and ISAT. The paper sums up the results of the experiment whose goal was to investigate the influence of concrete composition on the outputs of the above-mentioned methods. For the purposes of the experiment, specimens were made using 9 mixtures, which differed only in the amount of cement and plasticiser, i.e., the water/cement ratio. The experiment was designed and evaluated using the statistical methodology DOE (Design of Experiment). Next, the paper discusses a new view of the statistical evaluation of the test results of the methods described above.

Keywords: concrete, permeability, durability, design of experiment

Beton je eden najbolj uporabljanih materialov v gradbeništvu in njegova zdržljivost se proučuje z veliko pozornostjo. Lahko se reče, da je zdržljivost betona tesno povezana s prepustnostjo, na splošno s kvaliteto njegove površinske plasti. Ocena kvalitete površinske plasti betona je precej komplicirano vprašanje, h kateremu se lahko pristopi na različne načine. Avtorji tega članka se osredotočajo na tri mednarodno priznane metode - TPT, GWT in ISAT. Članek povzema rezultate preizkusa, katerega cilj je bil proučevati vpliv sestave betona na rezultate zgoraj omenjenih metod. Za namene preizkusa so bili vzorci izdelani iz 9 mešanic, ki so se razlikovale samo v količini cementa in plastifikatorja, to je razmerja voda/cement. Preizkusi so bili postavljeni in ocenjeni s statistično metodologijo DOE (angl. Design of Experiment). Nadalje članek obravnava nov pogled na statistično oceno rezultatov preizkusa in zgoraj opisanih metod.

Ključne besede: beton, prepustnost, trajnost, načrtovanje preizkusa

\section{INTRODUCTION}

The durability of hardened concrete and thus the whole structure greatly depends on the quality and permeability of the surface layer. A low permeability of the surface layer ensures a greater resistance to carbonation and entery of chlorides and other outside intrusions. ${ }^{1-3}$ These phenomena cause, among other things, corrosion of the steel reinforcement in concrete and thus its overall degradation. ${ }^{4,5}$ It is known that the quality of concrete is determined by the correct composition of fresh concrete and thus by the amount of cement, water and other additives and admixtures. ${ }^{6,7}$ There is a large number of rather different methods for determining the quality of a concrete surface layer. In terms of permeability, these methods can be divided into two groups - methods determining the resistance to the penetration of liquids or gases.

The durability of hardened concrete with respect to the quality of its surface layer is being dealt with in the
GACR 13-18870S project. One of the goals of the project is the assessment of existing test methodologies for the determination of the surface layer of concrete or the creation of new methodologies. A number of papers have been published within the project, such as ${ }^{8,9}$. Permeability itself is addressed in ${ }^{10-12}$.

The research described in this paper summarises an experiment whose goal was to assess the influence of concrete composition on the results of the tests determining the concrete surface layer's permeability, i.e., TPT, GWT and ISAT. For the purposes of the experiment, specimens were made using 9 mixtures, which differed only in the amount of cement and plasticiser, i.e., the water/cement ratio. The experiment was designed and evaluated using the statistical methodology DOE (Design of Experiment). These statistical methods are discussed in greater detail, e.g., in ${ }^{13}$. 


\section{EXPERIMENT PART}

\subsection{Testing methods}

\subsubsection{TPT method}

A TPT (Torrent Permeability Tester) is suitable for the determination of air permeability of the surface layer and can be used in both laboratory measurements and in-situ. The principle of determining the air permeability of concrete is in creating a vacuum on the surface layer and measuring the flow of air through the concrete into the measurement device over a set period of time. Table 1: Evaluation of the concrete cover by means of $k_{T}$ lists the quality categories of concrete cover as written in ${ }^{14}$.

Table 1: Evaluation of concrete cover by means of $k_{\mathrm{T}}$ Tabela 1: Ocena kvalitete površine betona s pomočjo $k_{\mathrm{T}}$

\begin{tabular}{|c|c|c|}
\hline Concrete cover quality & index & $k_{T}\left(\times 10^{-6} \mathrm{~m}^{2}\right)$ \\
\hline Very bad & 5 & $>10$ \\
\hline Bad & 4 & $1.0-10$ \\
\hline Medium & 3 & $0.1-1.0$ \\
\hline Good & 2 & $0.01-0.1$ \\
\hline Very good & 1 & $<0.01$ \\
\hline
\end{tabular}

This method is discussed more in ${ }^{14-18}$.

\subsubsection{ISAT method}

The second method used in the experiment, ISAT (Initial Surface Absorption Test), is used for determining the water permeability of the surface layer. Measurement by ISAT is performed exclusively with specimens in a laboratory. The principle of the test is the determination of the rate of water absorption (measured using a calibrated glass capillary) with a concrete cover of known area at a constant water pressure of a $200 \mathrm{~mm}$ water column. More can be found in ${ }^{19-21}$.

\subsubsection{GWT Method}

GWT (German Water Permeability Test) is also used for the measurement of concrete cover permeability to water but at constant water pressure of $0.02 \mathrm{MPa}$. The amount of water absorbed by the surface layer per unit of time is measured. This method can be used in-situ as well as on laboratory specimens. ${ }^{22}$

\subsection{Material}

The goal of the experiment was to assess the influence of the concrete composition on the results of TPT, ISAT and GWT tests while both the design and the experiment were evaluated using the DOE (Design Of Experiment) method.

The two main factors which were to decisively influence the concrete cover permeability were set to be cement and plasticiser content. The portion of these components in fresh concrete is determining for the amount of water and water/cement ratio as all the mixtures were always designed for S2 or S3 consistency according to ${ }^{23}$. The water/cement ratio was subsequently added into the calculation models as a third factor as the change in water/cement ratio best corresponds to the change of the overall composition of fresh concrete.

Plasticiser was added in $0 \%, 50 \%$ and $100 \%$ of the maximum amount recommended by the manufacturer. The amount of cement was increased in the mixture always by approx. $50 \mathrm{~kg} / \mathrm{m}^{3}$ of the concrete. In order to assess the broad spectrum of construction concretes, mixtures were prepared with 4 different contents of cement.

The authors first considered performing the research as a full factorial experiment 13 with the factors of the amount of cement and plasticiser, while the amount of cement was represented by four levels and the amount of plasticiser by three. However, some variants of these two factors did not meet the basic technological requirements for the production of concrete and therefore were eliminated from the experiment. The method of evaluation of the experimental results is described in the following sections of this paper.

Table 2: Design of experiment shows the concrete mixture matrix. The horizontal direction shows the amount of plasticiser from zero content to the maximum dose recommended by the manufacturer $(100 \%)$. The level of cement amount (vertical) is identified 0-III, while dose 0 corresponds approximately to $255 \mathrm{~kg} / \mathrm{m}^{3}$ of concrete and dose III to $405 \mathrm{~kg} / \mathrm{m}^{3}$ of concrete. The identification of the mixtures then corresponds to the portion of the components. Table 3: Composition of the mixtures shows the specific amounts of the components used. All the mixtures use the same aggregate from the same location and the same type of cement from one cement mill.

Table 2: Design of experiment

Tabela 2: Zasnova poskusa

\begin{tabular}{|c|c|c|c|}
\hline Cement / Plasticiser (\%) & $\mathbf{0}$ & $\mathbf{5 0}$ & $\mathbf{1 0 0}$ \\
\hline $\mathbf{0}$ & $\mathrm{R}$ & - & - \\
\hline I & $0 / 1$ & $1 / 1$ & - \\
\hline II & $0 / 2$ & $1 / 2$ & $2 / 2$ \\
\hline III & $0 / 3$ & $1 / 3$ & $2 / 3$ \\
\hline
\end{tabular}

Table 3: Composition of the mixtures

Tabela 3: Sestava mešanic

\begin{tabular}{|c|c|c|c|c|c|c|c|c|c|}
\hline \multirow{2}{*}{ Component } & \multicolumn{7}{|c|}{ Mixture } \\
\cline { 2 - 9 } & $\mathbf{R}$ & $\mathbf{0 / 1}$ & $\mathbf{0 / 2}$ & $\mathbf{0 / 3}$ & $\mathbf{1 / 1}$ & $\mathbf{1 / 2}$ & $\mathbf{1 / 3}$ & $\mathbf{2 / 2}$ & $\mathbf{2 / 3}$ \\
\hline $\begin{array}{c}\text { CEM I 42.5 } \\
\text { R (kg) }\end{array}$ & $\mathbf{2 4 8}$ & $\mathbf{3 0 8}$ & $\mathbf{3 5 7}$ & $\mathbf{3 9 2}$ & $\mathbf{2 9 5}$ & $\mathbf{3 4 9}$ & $\mathbf{3 9 4}$ & $\mathbf{3 3 8}$ & $\mathbf{3 8 6}$ \\
\hline $\begin{array}{c}\text { Bratcice 0-4 } \\
\text { mm (kg) }\end{array}$ & 953 & 925 & 889 & 826 & 927 & 897 & 846 & 905 & 854 \\
\hline $\begin{array}{c}\text { Olbramovice } \\
\text { 4-8 mm (kg) }\end{array}$ & 173 & 182 & 174 & 195 & 185 & 185 & 192 & 183 & 207 \\
\hline $\begin{array}{c}\text { Olbramovice } \\
\text { 8-16 mm } \\
\text { (kg) }\end{array}$ & 675 & 696 & 693 & 669 & 689 & 693 & 684 & 667 & 671 \\
\hline Water (kg) & 201 & 203 & 201 & 208 & 177 & 175 & 183 & 176 & 181 \\
\hline $\begin{array}{c}\text { faultPlasti- } \\
\text { ciser (kg) }\end{array}$ & $\mathbf{0}$ & $\mathbf{0}$ & $\mathbf{0}$ & $\mathbf{0}$ & $\mathbf{0 . 7 1}$ & $\mathbf{0 . 9 1}$ & $\mathbf{0 . 9 5}$ & $\mathbf{1 . 7 7}$ & $\mathbf{2 . 0 1}$ \\
\hline w/c (-) & $\mathbf{0 . 7 5}$ & $\mathbf{0 . 6 1}$ & $\mathbf{0 . 5 3}$ & $\mathbf{0 . 5 0}$ & $\mathbf{0 . 5 5}$ & $\mathbf{0 . 4 6}$ & $\mathbf{0 . 4 3}$ & $\mathbf{0 . 4 8}$ & $\mathbf{0 . 4 4}$ \\
\hline
\end{tabular}


P. MISÁK et al.: STATISTICAL VIEW OF EVALUATING CONCRETE-SURFACE-LAYER PERMEABILITY TESTS ...

Table 4: Properties of fresh concrete

Tabela 4: Lastnosti svežega betona

\begin{tabular}{|c|c|c|c|c|c|c|c|c|c|}
\hline \multirow{2}{*}{ Property } & \multicolumn{9}{|c|}{ Mixture } \\
\cline { 2 - 11 } & $\mathbf{R}$ & $\mathbf{0 / 1}$ & $\mathbf{0 / 2}$ & $\mathbf{0 / 3}$ & $\mathbf{1 / 1}$ & $\mathbf{1 / 2}$ & $\mathbf{1 / 3}$ & $\mathbf{2 / 2}$ & $\mathbf{2 / 3}$ \\
\hline Density $\left(\mathrm{kg} / \mathrm{m}^{3}\right)$ & 2250 & 2315 & 2315 & 2290 & 2275 & 2300 & 2300 & 2270 & 2300 \\
\hline Flow table test $(\mathrm{mm})$ & 435 & 410 & 385 & 415 & 360 & 350 & 370 & 340 & 330 \\
\hline Slump-test $(\mathrm{mm})$ & 110 & 60 & 60 & 110 & 60 & 50 & 60 & 65 & 50 \\
\hline Air content $(\%)$ & 2.8 & 2.7 & 2.5 & 2.5 & 3.6 & 2.8 & 3.2 & 4.5 & 3.0 \\
\hline
\end{tabular}

Fresh concrete for the production of specimens was always taken in conditions according to ${ }^{24}$. The properties of the fresh concrete tested according to ${ }^{23,25-27}$, are listed in Table 4: Properties of fresh concrete.

Beam specimens of size $300 \times 300 \times 150 \mathrm{~mm}$ were made from each mixture. Each specimen was tested three times with TPT and twice with GWT and ISAT. The results of ISAT were recorded at $60 \mathrm{~min}$ after the beginning of the test.

\section{RESULTS AND DISCUSSION}

The authors first performed a statistical analysis of the use of different distributions of probability for the quantities being observed mainly due to a strong absence of symmetry and normality in the test results. The non-normality of $k_{T}$ (TPT) has been discussed earlier, e.g., in ${ }^{16}$. The test results of the other parameters exhibit a similar statistical behaviour.

In order to test the most suitable distribution of probability, an additional experiment was conducted. The $k_{T}$ coefficient was determined on 32 specimens of size $300 \times 300 \times 80 \mathrm{~mm}$ using TPT. The measurement was performed in the same conditions in the shortest possible time interval and at a water content of $3.0 \%$ to $3.5 \%$. TPT was chosen mainly due to time economy.

The results of the tests are represented in the histogram in Figure 1 TPT result histogram. The most suitable probability distribution was chosen to be the lognormal distribution. This distribution generally appears suitable for a description of the quantities that exhibit high variability and at the same time the results are close

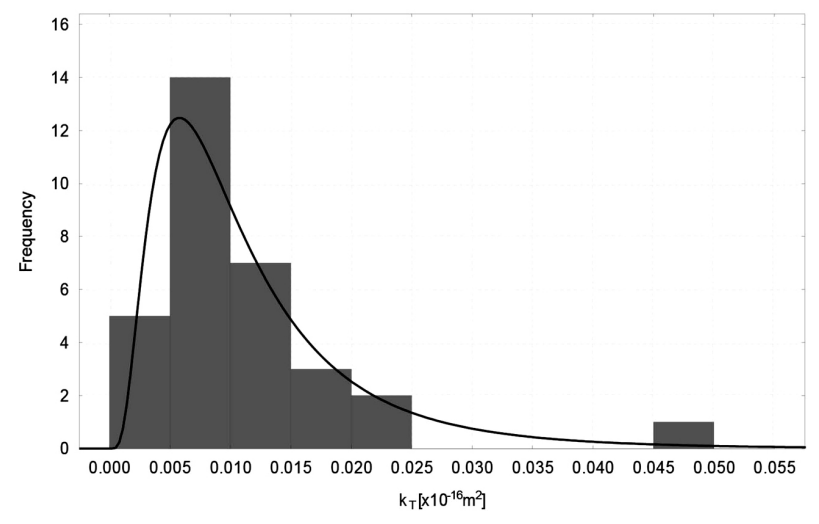

Figure 1: TPT result histogram

Slika 1: Histogram TPT-rezultatov to zero. The advantage of the lognormal probability distribution is, among others, the fact that it does not reach negative values. Tests of goodness of fit did not disprove the option of using a lognormal probability distribution in the output of GWT and ISAT.

In Tables 5 to 7 Measurement results - TPT through 7 show the basic statistical properties of the results of TPT, GWT, and ISAT performed on the above-described concrete mixtures with variable composition. The arithmetic average and the experimental standard deviation $s_{0}$ are supplemented with the calculation of $95 \%$ quantiles, which were determined using normal (identified by lower index n0.95) and lognormal (lower index $\ln 0.95$ ) probability distributions. The $95 \%$ quantile was used as the characteristic value of the quantities being observed (amend $\mathrm{D}$ of ${ }^{28}$ ). The value $V$ always identifies coefficient of variation in $\%$. All the values were determined at specimen mass water content within 3-3.5\%, which corresponded to the normal laboratory storage of the specimens.

Table 5: Measurement results - TPT

Tabela 5: Rezultati TPT-meritev

\begin{tabular}{|c|c|c|c|c|c|}
\hline Mixture & $\begin{array}{c}k_{\mathrm{T}} \\
\left(10^{-16} \mathrm{~m}^{2}\right)\end{array}$ & $\begin{array}{c}s_{0} \\
\left(10^{-16} \mathrm{~m}^{2}\right)\end{array}$ & $\begin{array}{c}V \\
(\%)\end{array}$ & $\begin{array}{c}k_{\mathrm{T} ; \ln 0.95} \\
\left(10^{-16} \mathrm{~m}^{2}\right)\end{array}$ & $\begin{array}{c}k_{\mathrm{T} ; \mathrm{n} 0.95} \\
\left(10^{-16} \mathrm{~m}^{2}\right)\end{array}$ \\
\hline $\mathbf{R}$ & 1.414 & 0.700 & 49.5 & 3.300 & 2.566 \\
\hline $\mathbf{0 / 1}$ & 0.052 & 0.013 & 25.0 & 0.075 & 0.072 \\
\hline $\mathbf{0 / 2}$ & 0.042 & 0.016 & 38.1 & 0.072 & 0.068 \\
\hline $\mathbf{0 / 3}$ & 0.018 & 0.007 & 38.9 & 0.030 & 0.029 \\
\hline $\mathbf{1 / 1}$ & 0.035 & 0.014 & 40.0 & 0.067 & 0.059 \\
\hline $\mathbf{1 / 2}$ & 0.030 & 0.014 & 46.7 & 0.056 & 0.053 \\
\hline $\mathbf{1 / 3}$ & 0.016 & 0.004 & 25.0 & 0.023 & 0.023 \\
\hline $\mathbf{2 / 2}$ & 0.032 & 0.007 & 21.9 & 0.045 & 0.044 \\
\hline $\mathbf{2 / 3}$ & 0.014 & 0.003 & 21.4 & 0.019 & 0.019 \\
\hline
\end{tabular}

Table 6: Measurement results - GWT

Tabela 6: Rezultati GWT-meritev

\begin{tabular}{|c|c|c|c|c|c|}
\hline Mixture & $\begin{array}{c}k_{\mathrm{T}} \\
\left(10^{-16} \mathrm{~m}^{2}\right)\end{array}$ & $\begin{array}{c}s_{0} \\
\left(10^{-16} \mathrm{~m}^{2}\right)\end{array}$ & $\begin{array}{c}V \\
(\%)\end{array}$ & $\begin{array}{c}k_{\mathrm{T} ; \ln 0.95} \\
\left(10^{-16} \mathrm{~m}^{2}\right)\end{array}$ & $\begin{array}{c}k_{\mathrm{T} ; \mathrm{n} 0.95} \\
\left(10^{-16} \mathrm{~m}^{2}\right)\end{array}$ \\
\hline $\mathbf{R}$ & 10.70 & 1.67 & 15.6 & 13.70 & 13.50 \\
\hline $\mathbf{0 / 1}$ & 5.21 & 0.14 & 2.7 & 7.88 & 7.45 \\
\hline $\mathbf{0 / 2}$ & 4.60 & 0.13 & 2.8 & 7.02 & 6.67 \\
\hline $\mathbf{0 / 3}$ & 1.20 & 0.25 & 20.8 & 1.73 & 1.61 \\
\hline $\mathbf{1 / 1}$ & 2.13 & 0.28 & 13.1 & 2.62 & 2.59 \\
\hline $\mathbf{1 / 2}$ & 1.78 & 0.40 & 22.5 & 2.51 & 2.44 \\
\hline $\mathbf{1 / 3}$ & 1.24 & 0.28 & 22.6 & 1.78 & 1.70 \\
\hline $\mathbf{2 / 2}$ & 1.43 & 0.31 & 21.7 & 2.04 & 1.94 \\
\hline $\mathbf{2 / 3}$ & 0.59 & 0.06 & 10.2 & 0.70 & 0.69 \\
\hline
\end{tabular}




\section{MATERIALI IN TEHNOLOGIJE/MATERIALS AND TECHNOLOGY (1967-2017) - 50 LET/50 YEARS}

\section{P. MISÁK et al.: STATISTICAL VIEW OF EVALUATING CONCRETE-SURFACE-LAYER PERMEABILITY TESTS ...}

In order to determine the influence of the individual factors (water/cement ratio, cement and plasticiser content) on the permeability of the surface layer, the experiment was analysed using DOE. Using the appropriate SW, this method enables an easy identification of such factors that have a significant statistical influence on the quantity being observed.

Table 7: Measurement results - ISAT after $60 \mathrm{~min}$

Tabela 7: Rezultati ISAT-meritev po $60 \mathrm{~min}$

\begin{tabular}{|c|c|c|c|c|c|}
\hline Mixture & $\begin{array}{c}f_{60} \\
\left(\mathrm{~mL} / \mathrm{m}^{2} / \mathrm{s}\right)\end{array}$ & $\begin{array}{c}s_{0} \\
\left(\mathrm{~mL} / \mathrm{m}^{2} / \mathrm{s}\right)\end{array}$ & $\begin{array}{c}V \\
(\%)\end{array}$ & $\begin{array}{c}f_{60 ; \ln 0.95} \\
\left(\mathrm{~mL} / \mathrm{m}^{2} / \mathrm{s}\right)\end{array}$ & $\begin{array}{c}f_{60 ; \mathrm{n} 0.95} \\
\left(\mathrm{~mL} / \mathrm{m}^{2} / \mathrm{s}\right)\end{array}$ \\
\hline $\mathrm{R}$ & 0.334 & 0.061 & 18.3 & 0.441 & 0.434 \\
\hline $0 / 1$ & 0.260 & 0.024 & 9.2 & 0.301 & 0.299 \\
\hline $0 / 2$ & 0.227 & 0.027 & 11.9 & 0.274 & 0.271 \\
\hline $0 / 3$ & 0.141 & 0.008 & 5.7 & 0.155 & 0.155 \\
\hline $1 / 1$ & 0.211 & 0.042 & 19.9 & 0.291 & 0.281 \\
\hline $1 / 2$ & 0.140 & 0.007 & 5.0 & 0.151 & 0.151 \\
\hline $1 / 3$ & 0.101 & 0.012 & 11.9 & 0.122 & 0.121 \\
\hline $2 / 2$ & 0.118 & 0.006 & 5.1 & 0.128 & 0.128 \\
\hline $2 / 3$ & 0.077 & 0.023 & 29.9 & 0.100 & 0.098 \\
\hline
\end{tabular}

During multiple factor analysis it is very important not to consider only the individual factors, but also to test their influence at the same time. There are a number of advantages. Especially, it is possible to assess the mutual interactions of the factors and, moreover, to minimise the errors of statistical tests. This paper contains all

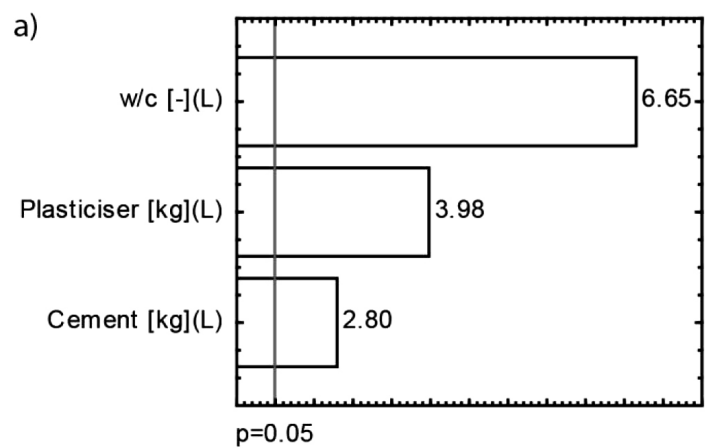

b)

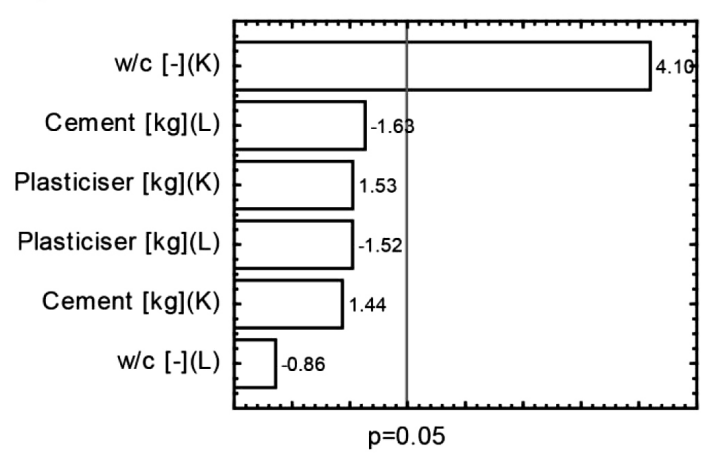

Figure 2: TPT: a) Pareto chart of standardised assessment of effects linear model, b) Pareto chart of standardised assessment of effects each effect represented in linear (L) and quadratic (K) form Slika 2: TPT: a) Pareto diagram standardizirane ocene učinkov linearni model, b) Pareto diagram standardizirane ocene učinkov vsak učinek je predstavljen v linearni (L) in kvadratni (K) obliki the effects of the factors as well as their interactions assessed by means of the so-called analysis of variance (ANOVA) on the significance level of 0.05 , whose outcomes are subsequently processed into Pareto charts. ${ }^{13,29}$

As mentioned above, the experiment was not designed as a full factorial experiment; all factor options (mixture compositions) were not put to combination. Analytical tools of the so-called central composite design were used as the evaluation apparatus.

The authors used three basic models for the output quantities of TPT, GWT and ISAT. In the first model, all the factors are represented only in the linear form (Equation (1)) and in the second one, in linear and quadratic form (Equation (2)). The third model involves more factor interactions (Equation (3)). For simplicity, in all formulae, factors are represented by $x_{i}$ and regression coefficients $a_{i} . y$ represent the output quantity, i.e., $k_{T}$ or $f_{60}$ :

$$
\begin{aligned}
& y=a_{1} x_{1}+a_{2} x_{2}+a_{3} x_{3} \\
& y=a_{1} x_{1}+a_{2} x_{1}^{2}+\ldots+a_{5} x_{3}+a_{6} x_{3}^{2} \\
& y=a_{1} x_{1}+\ldots+a_{3} x_{3}+a_{2} x_{1}^{2}+\ldots+a_{6} x_{3}^{2}+a_{12} x_{1} x_{2}+\ldots+a_{23} x_{2} x_{3}
\end{aligned}
$$

Figures $\mathbf{2 a}, \mathbf{2} \mathbf{b}$ and $\mathbf{3}$ show the outcomes of the analysis of variance of the $k_{T}$ coefficient (TPT) performed on models according to (1) through (3) as standardised assessments of the effects. A standardised assessment of the effect is in the case of this application test statistic - if it exceeds 0.05 on the level of significance, it can be assumed that the given factor (or interaction of factors) has a statistically significant influence on the output quantity $y$. Based on this simple linear model (Equation (1) and Figure 2a)) all the factors are statistically significant. When introducing the quadratic elements (Equation (2) and Figure 2b), the evaluation showed, as the only statistically significant factor, the square of water/cement ratio, which thus

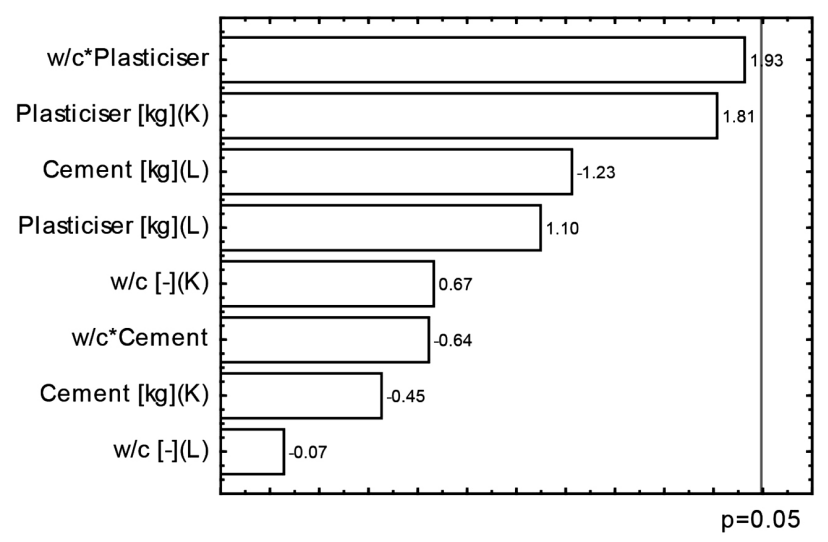

Figure 3: TPT: Pareto chart of standardised assessment of effects linear $(\mathrm{L})$ as well as quadratic $(\mathrm{K})$ representation of effects and their interaction $(*)$

Slika 3: TPT: Pareto diagram standardizirane ocene učinkov linearna (L) kot tudi kvadratna $(\mathrm{K})$ predstavitev učinkov in njihov medsebojni vpliv (*) 

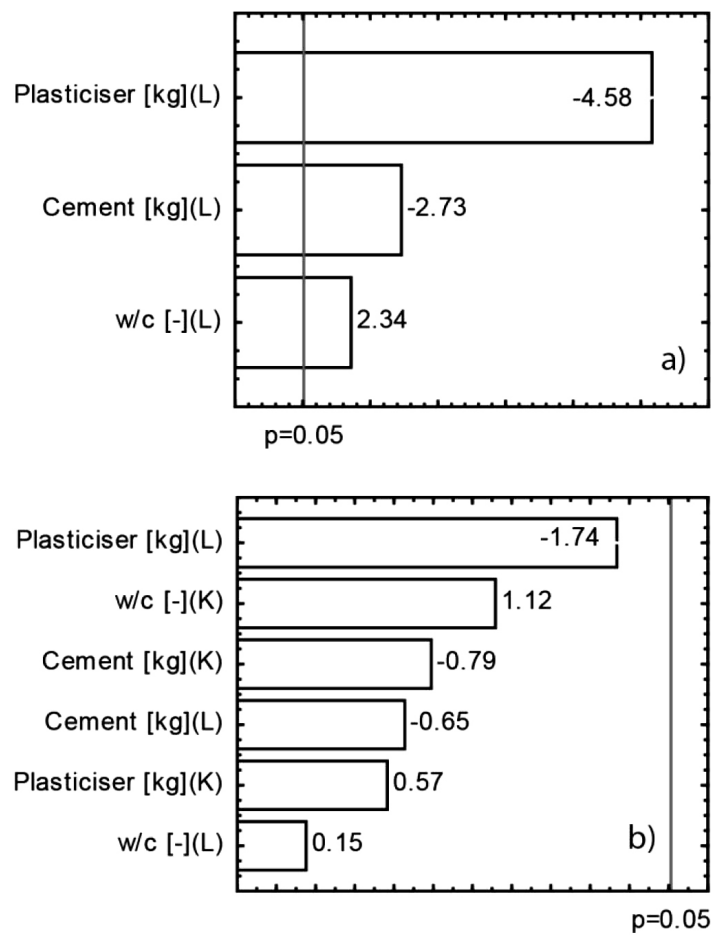

Figure 4: ISAT: a) Pareto chart of standardised assessment of effects linear model, b) Pareto chart of standardised assessment of effects each effect represented in linear (L) and quadratic (K) form

Slika 4: ISAT: a) Pareto diagram standardizirane ocene učinkov linearni model, b) Pareto diagram standardizirane ocene učinkov vsak učinek je predstavljen v linearni (L) in kvadratni (K) obliki

appears to be the most statistically important factor. The interactions of some of the factors were eliminated from the analysis of the complex model (Equation (3)) because of the clear correlation between them. However, the analysis thus performed did not determine any factor nor combination as being statistically significant.

Based on these calculations it can be said that the permeability of the surface layer of the concrete determined by TPT depends mainly on the water/cement

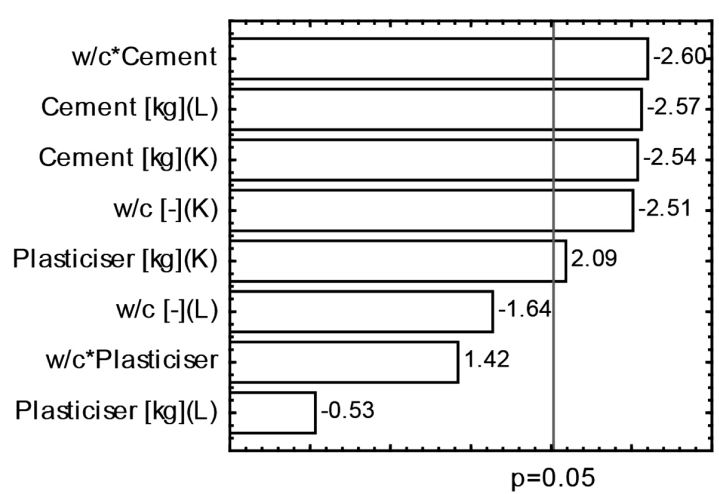

Figure 5: ISAT: Pareto chart of standardised assessment of effects linear (L) as well as quadratic (K) representation of effects and their interaction $(*)$

Slika 5: ISAT: a) Pareto diagram standardizirane ocene učinkov linearna (L) kot tudi kvadratna (K) predstavitev učinkov in njihovega medsebojnega vpliva $(*)$ ratio. The analysis of the GWT results arrived at the same results.

In the case of $f_{60}$ measured by means of ISAT, the statistical evaluation is different. The linear model (Equation (1) and Figure 4a)) showed the significance of all the factors, much like in the previous cases, however, in different order. According to Equation (2) and Figure $\mathbf{4 b}$, no factor or a square of a factor is significant. Only the use of the third model (Equation (3) and Figure 5) enabled a better identification of statistically significant factors, which were determined to be mainly water/cement ratio and cement content.

Based on the analyses it can be said that the observed quantities, i.e., TPT, GWT and ISAT outputs, are determined mainly by the water/cement ratio. However, the significance of the water/cement ratio is not statistically large enough for the representation of the other components to be neglected. Nevertheless, the water/cement ratio is very suitable for a simple visualisation of the surface layer permeability values, Figure 6 through 8. These charts show the results of all the methods using a logarithmic scale. In all cases, the exponential formula was evaluated as best:

$$
y=a e^{b\left(\frac{w}{c}\right)}
$$

where $a$ and $b$ are the regression coefficients and $w / c$ signifies the water/cement ratio. Table 8: Regression coefficients show values of the regression coefficients and the coefficients of determination.

Table 8: Regression coefficients

Tabela 8: Regresijski koeficienti

\begin{tabular}{|c|c|c|c|}
\hline Method & $a$ & $b$ & $R^{2}$ \\
\hline TPT & $5 \mathrm{E}-05$ & 12.705 & 0.86 \\
\hline GWT & 0.343 & 7.877 & 0.80 \\
\hline ISAT & 0.017 & 4.223 & 0.80 \\
\hline
\end{tabular}

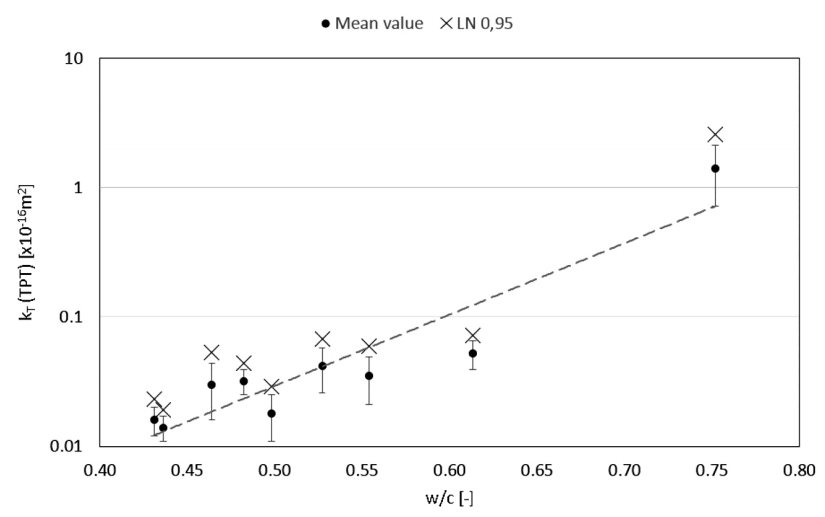

Figure 6: Relationship between $w / c$ ratio and $k_{\mathrm{T}}$ value (TPT method) with standard deviation and characteristic value (lognormal probability distribution)

Slika 6: Odvisnost med $w / c$ razmerjem in vrednostjo $k_{\mathrm{T}}$ (TPT metoda) s standardnim odkolonom in značilno vrednostjo (logaritemska normalna razporeditev verjetnosti) 


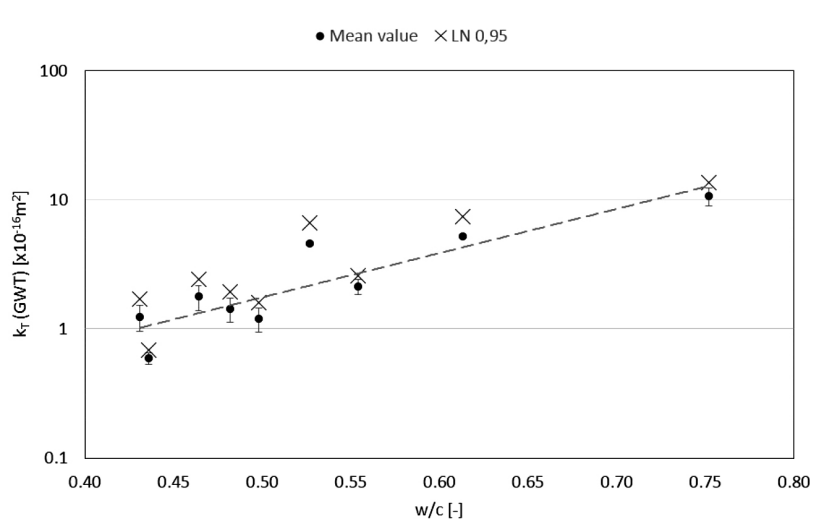

Figure 7: Relationship between $w / c$ ratio and $k_{\mathrm{T}}$ value (GWT method) with standard deviation and characteristic value (lognormal probability distribution)

Slika 7: Odvisnost med $w / c$ razmerjem in vrednostjo $k_{\mathrm{T}}$ (GWT metoda) s standardnim odklonom in značilno vrednostjo (logaritemska

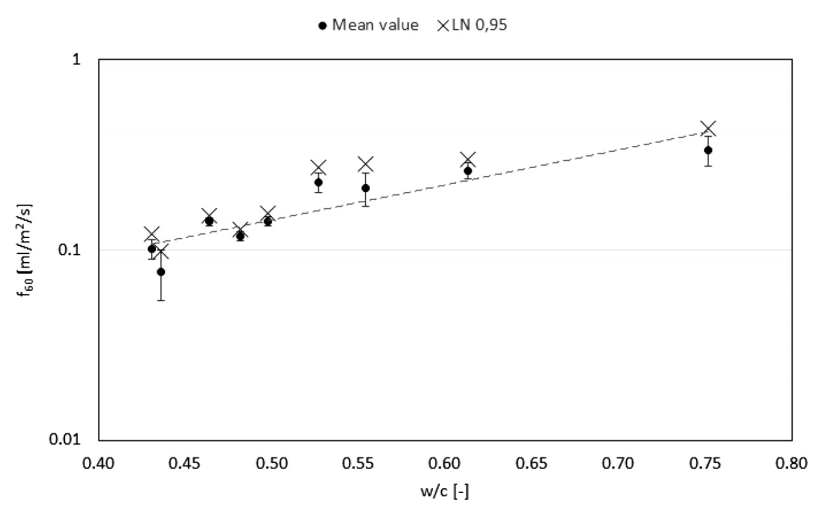

Figure 8: Relationship between $w / c$ ratio and $f_{60}$ value (ISAT method) with standard deviation and characteristic value (lognormal probability distribution)

Slika 8: Odvisnost med $w / c$ razmerjem in vrednostjo $f_{60}$ (ISAT metoda) s standardnim odklonom in značilno vrednostjo (logaritemska normalna razporeditev verjetnosti)

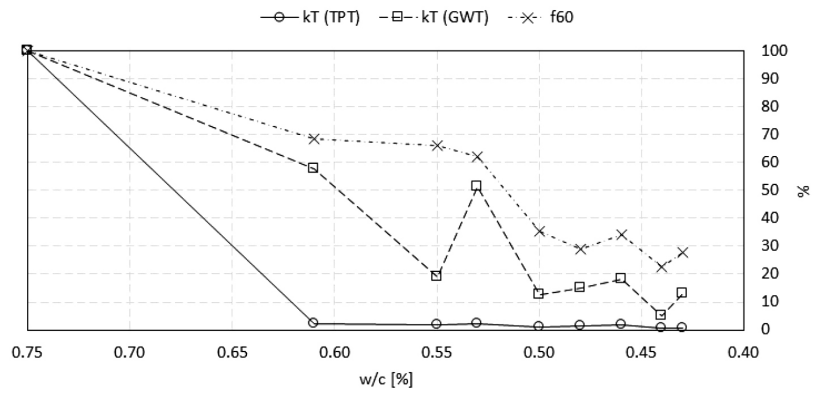

Figure 9: Percentage drop of the results of the observed methods depending on water/cement ratio

Slika 9: Odstotkovno zmanjšanje rezultatov v odvisnosti od razmerja voda/cement

Figure 9 shows the percentage drop of the test results dependent on the water/cement ratio. The results relate to the values measured on the mixture with the highest water/cement ratio, i.e., mixture R. As the chart indicates, the test results of all the methods were able to

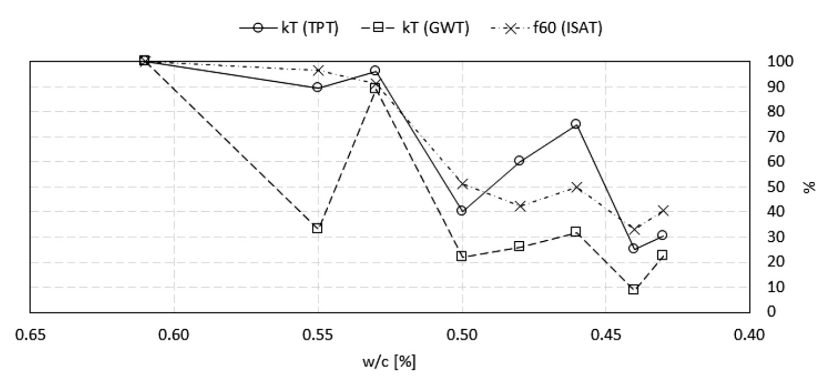

Figure 10: Percentage drop of the results of the observed methods depending on the water/cement ratio without mixture $\mathrm{R}$

Slika 10: Odstotkovno zmanjšanje rezultatov opazovanih metod v odvisnosti od razmerja voda/cement, brez zmesi R

capture the change in the permeability depending on the change in the water/cement ratio (with rare exceptions). Figure 9 also indicates that the mixture $\mathrm{R}$ is not entirely suitable as a reference. In particular, the results of TPT are difficult to distinguish for this setting. Figure 10 shows the same percentage representation of the results after eliminating mixture $\mathrm{R}$ - the reference mixture was chosen to be the mixture with the highest water/cement ratio, i.e., 0/1. Figure $\mathbf{1 0}$ better shows the drop in the permeability of the surface layer depending on the water/cement ratio, especially in the case of the TPT results.

\section{CONCLUSIONS}

The experiments and their analyses indicate the following:

Given the relatively high variability of the test results (especially in the case of TPT - the lowest coefficient of variation was $21.4 \%$ in concrete identified as $2 / 3$ ) the more suitable characteristic appears to be the $95 \%$ quantile, as opposed to only the arithmetic average.

The lognormal distribution appears suitable for the evaluation of the results of concrete cover permeability test using TPT, GWT and ISAT. The reason is mainly the limitation of this distribution for negative values. The use of a normal distribution can probably cause a number of problems. As seen in Table 5: Measurement results TPT through 7 , the value of the $95 \%$ quantile determined using a normal probability distribution is probably always lower than the value of the $95 \%$ quantile determined using a lognormal distribution. The evaluation of the quality of the concrete cover according to a normal distribution brings higher values.

The authors find it appropriate to slightly adapt the current way of categorising the surface layer of concrete, e.g., according to Table 1: Evaluation of concrete cover by means of $k_{T}$. A simple categorisation into 5 groups is certainly useful; however, the experiment shows that the limits thus set do not sufficiently capture the significant changes in the concrete composition. The TPT and test result evaluation were first published more than 20 years ago $^{14}$ and experiments then performed no longer correspond to the results of contemporary concrete. The 
authors believe that a solution to this situation can be the adjustment of existing limits of the categories and performing the categorisation using $95 \%$ quantile instead of the arithmetic average. The introduction of a similar categorisation system would be suitable in the other methods as well.

The water/cement ratio seems to have the most significant influence on the results of the concrete cover permeability tests. However, the significance of the water/cement coefficient is not statistically large enough for the content of the other components to be neglected.

The results of all the methods used in the experiment reacted to a change in the concrete composition with similar trends of concrete cover permeability reduction, especially with respect to its water/cement ratio.

The set of methods called DOE (Design Of Experiment) appears to be a suitable tool for the design and evaluation of similar experiments.

\section{Acknowledgement}

This paper was elaborated with the financial support of the Czech Science Foundation project GAČR 13-18870S and European Union's Operational Programme Research and Development for Innovations, No. CZ.1.05/2.1.00/03.0097.

\section{REFERENCES}

${ }^{1}$ S. Han, W. Park, E. Yang, Evaluation of concrete durability due to carbonation in harbour concrete structures, Construction and Building Materials, 48 (2013), 1045-1049, doi:10.1016/j.conbuildmat.2013.07.057

${ }^{2}$ B. Salvoldi, H. Beushausen, M. Alexander, Oxygen permeability of concrete and its relation to carbonation, Construction and Building Materials, 85 (2015), 30-37, doi:10.1016/j.conbuildmat.2015.02.019

${ }^{3}$ D. Chopra, R. Siddique, Strength, permeability and microstructure of self-compacting concrete containing rice husk ash, Biosystems Engineering, 130 (2015), 72-80, doi:10.1016/j.biosystemseng.2014. 12.005

${ }^{4}$ G. Roventi, T. Bellezze, G. Giuliani, C. Conti, Corrosion resistance of galvanized steel reinforcements in carbonated concrete: effect of wet-dry cycles in tap water and in chloride solution on the passivating layer, Cement and Concrete Research, 65 (2014), 76-84, doi:10.1016/j.cemconres.2014.07.014

${ }^{5}$ J. Ribeiro, Z. Panossian, S. Selmo, Proposed criterion to assess the electrochemical behavior of carbon steel reinforcements under corrosion in carbonated concrete structures after patch repairs, Construction and Building Materials, 40 (2013), 40-49, doi:10.1016/j.conbuildmat.2012.09.097

${ }^{6}$ J. Chen, A. Kwan, Y. Jiang, Adding limestone fines as cement paste replacement to reduce water permeability and sorptivity of concrete, Construction and Building Materials, 56 (2013), 87-93, doi:10.1016/ j.conbuildmat.2014.01.066

${ }^{7}$ L. Dellinghausen, A. Gastaldini, F. Vanzin, K. Veiga, Total shrinkage, oxygen permeability, and chloride ion penetration in concrete made with white Portland cement and blast-furnace slag, Construction and Building Materials, 37 (2013), 652-659, doi:10.1016/j.conbuildmat.2012.07.076

${ }^{8}$ L. Topolář, H. Šimonová, P. Misák, Effect of Concrete Mixture Composition on Acoustic Emission and Fracture Parameters
Obtained from Three-Point Bending Test, Advanced Materials Research, 1100 (2015), 152-155, doi:10.4028/www.scientific.net/ AMR.1100.152

${ }^{9}$ M. Matysík, L. Topolář, P. Daněk, H. Šimonová, T. Vymazal, I. Plšková, An Experimental Study on Acoustic Emission Signals during the Three-Point Bending Fracture Test, Advanced Materials Research, 1000 (2014), 281-284, doi:10.4028/www.scientific.net/ AMR.1000.281

${ }^{10}$ T. Stavař, M. Stehlík, The Assessment of Durability of Fibre Concretes with Dense Aggregate and Concrete Recyclate from the Results of Permeability and Diffusion Tests, Advanced Materials Research, 1100 (2015), 106-111, doi:10.4028/www.scientific.net/ AMR.1100.106

${ }^{11}$ M. Stehlík, V. Hermánková, L. Vítek, Opening of microcracks and air permeability in concrete, Journal of Civil Engineering and Management, 21 (2015), 177-184, doi:10.3846/13923730.2013. 802721

${ }^{12}$ M. Stehlík, Enhancing the durability of concrete made of concrete recyclate by additives and admixtures, Journal of Civil Engineering and Management, 20 (2014), 270-279, doi:10.3846/13923730.2013. 802708

${ }^{13}$ L. Eriksson, Design of experiments: principles and applications, 3. (2008), rev. and enl. ed. Umetrics Academy, Umeå

${ }^{14} \mathrm{R}$. Torrent, A two-chamber vacuum cell for measuring the coefficient of permeability to air of the concrete cover on site, Materials and Structures, 25 (1992), 358-365, doi:10.1007/BF02472595

${ }^{15}$ L. Zong, Z. Fei, S. Zhang, Permeability of recycled aggregate concrete containing fly ash and clay brick waste, Journal of Cleaner Production, 70 (2014), 175-182, doi:10.1016/j.jclepro.2014.02.040

${ }^{16}$ B. Kucharczyková, P. Misák, T. Vymazal, Determination and evaluation of the air permeability coefficient using Torrent Permeability Tester, Russian Journal of Nondestructive Testing, 46 (2010), 226-233, doi:10.1134/S1061830910030113

${ }^{17}$ SN 505 262/1:2003 - Construction en béton -Spécifications complémentaires: Annexe E: "Perméabilité à l'airdans les structures", NS, Switzerland

${ }^{18}$ Recommendation of RILEM TC 189-NEC "Non-destructive evaluation of the concrete cover": Comparative test - Part I, Materials and Structures, 38 (2005), 895-906, doi:10.1617/14384

${ }^{19} \mathrm{P}$. Claisse, Surface tests to determine transport properties of concrete - I: the tests, Transport Properties of Concrete, (2014), 26, Elsevier

${ }^{20}$ B. Sabir, S. Wild, M. O'Farrell, A water sorptivity test for martar and concrete, Materials and Structures, 31 (1998), 568-574, doi:10.1007/BF02481540

${ }^{21}$ BS 1881-122:2011 - Testing concrete. Method for determination of water absorption. BSI, UK

${ }^{22}$ Nondestructive testing of materials and structures: proceedings of NDTMS-2011, (2013), Istanbul, Turkey, May 15-18, 2011. 2 sv.

${ }^{23}$ EN 12350-2:2009 - Testing fresh concrete - Part 2: Slump-test ÚNMZ, Prague

${ }^{24}$ EN 12350-1:2009 Testing fresh concrete - Part 1: Sampling ÚNMZ, Prague

${ }^{25}$ EN 12350-5:2009 Testing fresh concrete - Part 5: Flow table test ÚNMZ, Prague

${ }^{26}$ EN 12350-6:2009 Testing fresh concrete - Part 6: Density ÚNMZ, Prague

${ }^{27}$ EN 12350-7:2009 Testing fresh concrete - Part 7: Air content Pressure methods ÚNMZ, Prague

${ }^{28}$ EN 1990:2015 Eurocode: Basis of structural design, 2 ed. ÚNMZ, Prague

${ }^{29}$ M. Fritz, P. Berger, Comparing more than two means, Improving the User Experience Through Practical Data Analytics, (2015), 163, Elsevier 